\title{
Numerical Simulation and Modeling on Thermal Cooling of Fuel Cell Using Water Based $\mathrm{Al}_{2} \mathrm{O}_{3}$, $\mathrm{SiC}$ and $\mathrm{CuO}$ Nanofluids
}

\author{
N. K. Kund
}

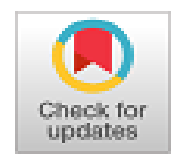

\begin{abstract}
Simulation codes are generated and implemented on water based $\mathrm{Al}_{2} \mathrm{O}_{3}$, SiC and $\mathrm{CuO}$ nanofluids. The situation visualizes on fuel cell heat management. It evaluates thermal field/contour besides fuel cell temperature. Ultimately, for all the quoted nanofluids, the fuel cells temperatures remain quite below the critical breakdown value of $356 \mathrm{~K}$. Furthermore, for all the quoted nanofluids, the thermal fields/contours range between fuel cells edges and ambient values. Despite the resemblances in thermal fields/contours, the dissimilarities are in consequence of the deviances in thermophysical properties of enumerated nanomaterials. Besides, fuel cell temperatures of $350 \mathrm{~K}, 322 \mathrm{~K}$ and $340 \mathrm{~K}$ are observed with water based $\mathrm{Al}_{2} \mathrm{O}_{3}, \mathrm{SiC}$ and $\mathrm{CuO}$ nanofluids, respectively. In addition, the water based SiC nanofluid extracts optimum fuel cell heat management. Because, the water based SiC nanofluid corresponds to the minimum follow-on fuel cell temperature of $322 \mathrm{~K}$ as well.
\end{abstract}

Index Terms: Simulation Codes, Heat Management, Fuel Cell, $\mathrm{Al}_{2} \mathrm{O}_{3}, \mathrm{SiC}, \mathrm{CuO}$, Nanofluids.

\section{INTRODUCTION}

Unquestionably, the fuel cells have got wide industrial and domestic applications. However, the fuel cell heat management still remains the toughest ever challenge. A typical fuel cell is demonstrated in figure 1 . The natural/atmospheric heat management remains inapt for tremendously high heat generation circumstances. Nevertheless, in the last few decades the abnormal method of heat management or heat removal has compelled the investigators for further research in fuel cell heat management.

However, the nanofluid heat management remains incomparable. It is because the natural/atmospheric heat management is feeble to support the target. Also, the experimental and CFD researches on solidification remain demonstrated in texts [1-7]. Numerical assessments on heat management over rectangular field also endure within literature [8-25].

It is realized that the nanofluid heat management (rather than the natural/atmospheric heat management) evades the problems of high heat generations and hereafter, the nanofluid

Revised Manuscript Received on October 30, 2019.

* Correspondence Author

N. K. Kund, Department of Production Engineering, Veer Surendra Sai University of Technology, Burla (Sambalpur), Odisha, India.

(C) The Authors. Published by Blue Eyes Intelligence Engineering and Sciences Publication (BEIESP). This is an open access article under the CC BY-NC-ND license (http://creativecommons.org/licenses/by-nc-nd/4.0/) cooling stands as the momentous get-up-and-go of the present assessment. Here, the fuel cell heat management with water based $\mathrm{Al}_{2} \mathrm{O}_{3}$, $\mathrm{SiC}$ and $\mathrm{CuO}$ nanofluids remain accomplished numerically.

\section{DEMONSTRATION OF PHYSICAL PROBLEM}

Figure 2 demonstrates the computational domain of fuel cell where top and bottom faces represent heat evolution. Remaining faces represent the ambient conditions. Here, the fuel cell heat management with water based $\mathrm{Al}_{2} \mathrm{O}_{3}, \mathrm{SiC}$ and $\mathrm{CuO}$ nanofluids remain accomplished numerically.

Besides, the thermophysical properties of $\mathrm{Al}_{2} \mathrm{O}_{3}, \mathrm{SiC}$ and $\mathrm{CuO}$ nanoparticles and model data of the computational domain remain presented in Table 1.

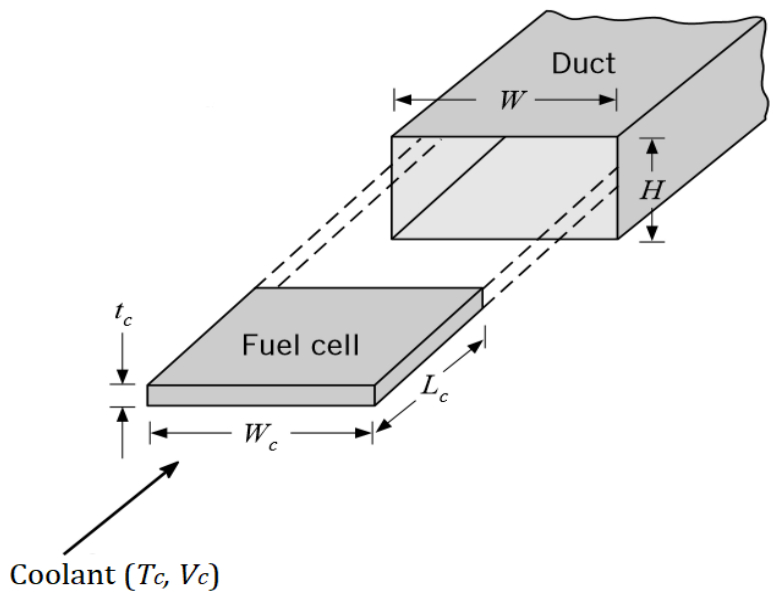

Figure 1. Fuel cell with enclosure

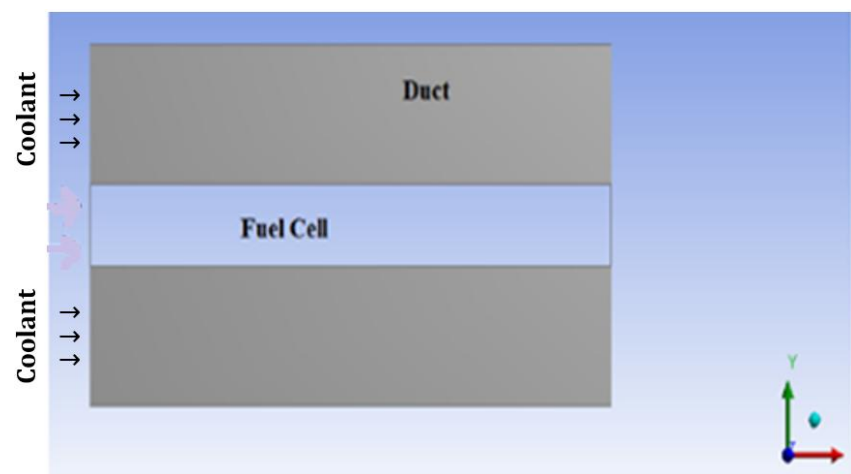

Figure 2. Computational domain 


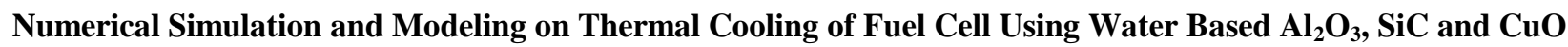
Nanofluids

Table 1. Thermophysical properties and model data.

\begin{tabular}{|l|l|l|l|}
\hline Nanoparticle Properties & $\mathbf{A l}_{2} \mathbf{O}_{3}$ & SiC & $\mathbf{C u O}$ \\
\hline Density, $\rho\left(\mathrm{Kg} / \mathrm{m}^{3}\right)$ & 3971 & 3161 & 6316 \\
\hline Specific heat, $C_{P}\left({\left.\mathrm{~J} . \mathrm{Kg}^{-1} . \mathrm{K}^{-1}\right)}^{\prime}\right.$ conductivity, $k$ & 37 & 495 & 34 \\
\hline $\begin{array}{l}\text { Thermal } \\
(\mathrm{W} / \mathrm{m}-\mathrm{K})\end{array}$ & \multicolumn{3}{|l|}{ Values } \\
\hline Model Data & $25 \mathrm{~mm}$ \\
\hline Enclosure height $(\mathrm{H})$ & $51 \mathrm{~mm}$ \\
\hline Fuel cell length $\left(\mathrm{L}_{\mathrm{c}}\right)$ & $5 \mathrm{~mm}$ \\
\hline Thickness of fuel cell $\left(\mathrm{t}_{\mathrm{c}}\right)$ & $51 \mathrm{~mm}$ \\
\hline Fuel cell width $\left(\mathrm{W}_{\mathrm{c}}\right)$ & $51 \mathrm{~mm}$ \\
\hline Enclosure width $(\mathrm{W})$ & $300 \mathrm{~K}$ \\
\hline Atmospheric temperature & $10 \mathrm{~W} / \mathrm{cm}^{2}$ \\
\hline Fuel cell heat flux & $8 \mathrm{~m} / \mathrm{s}$ \\
\hline Coolant velocity &
\end{tabular}

\section{NUMERICAL PROCEDURES}

Equations of mass, momentum and energy remain presented with equalities 1-4. Linearized form of discretized equations are computed by running simulation codes. Usual steps like meshing and initialization stand chosen for running the simulation codes. It is intended for getting thermal fields/countours within computational domain presented previously in figure 2.

Continuity:

$$
\frac{\partial u}{\partial x}+\frac{\partial v}{\partial y}=0
$$

$\mathrm{X}$-momentum:

$$
\rho\left(\frac{\partial u}{\partial t}+u \frac{\partial u}{\partial x}+v \frac{\partial v}{\partial y}\right)=-\frac{\partial p}{\partial x}+\mu\left(\frac{\partial^{2} u}{\partial x^{2}}+\frac{\partial^{2} u}{\partial y^{2}}\right)
$$

Y-momentum:

$$
\rho\left(\frac{\partial v}{\partial t}+u \frac{\partial v}{\partial x}+v \frac{\partial v}{\partial y}\right)=-\frac{\partial p}{\partial y}+\mu\left(\frac{\partial^{2} v}{\partial x^{2}}+\frac{\partial^{2} v}{\partial y^{2}}\right)+\rho g
$$

Energy:

$$
\left(\frac{\partial T}{\partial t}+u \frac{\partial T}{\partial x}+v \frac{\partial T}{\partial y}\right)=\alpha\left(\frac{\partial^{2} T}{\partial x^{2}}+\frac{\partial^{2} T}{\partial y^{2}}\right)
$$

Here, simulation codes are developed and exercised with water based $\mathrm{Al}_{2} \mathrm{O}_{3}, \mathrm{SiC}$ and $\mathrm{CuO}$ nanofluids. The situation visualizes on fuel cell heat management. Equations of mass, momentum and energy remain computed for the same. Time step chosen in the present computation is $0.0001 \mathrm{~s}$.

\section{RESULTS AND DISCUSSIONS}

Simulation codes are generated and implemented on water based $\mathrm{Al}_{2} \mathrm{O}_{3}, \mathrm{SiC}$ and $\mathrm{CuO}$ nanofluids. The situation visualizes on fuel cell heat management. It evaluates thermal field/contour besides fuel cell temperature.

\section{Effect of Water- $\mathrm{Al}_{2} \mathrm{O}_{3}$ Nanofluid on Fuel Cell Cooling}

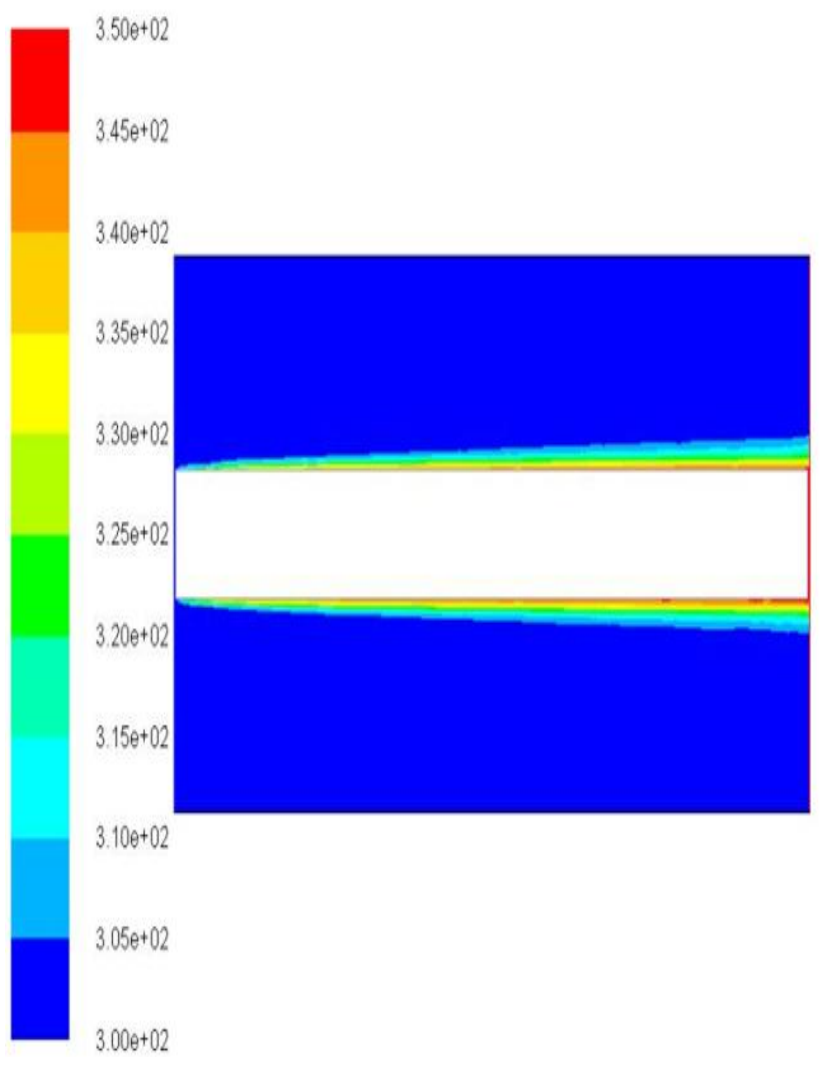

Figure 3. Temperature field with water- $-\mathrm{Al}_{2} \mathrm{O}_{3}$ nanofluid

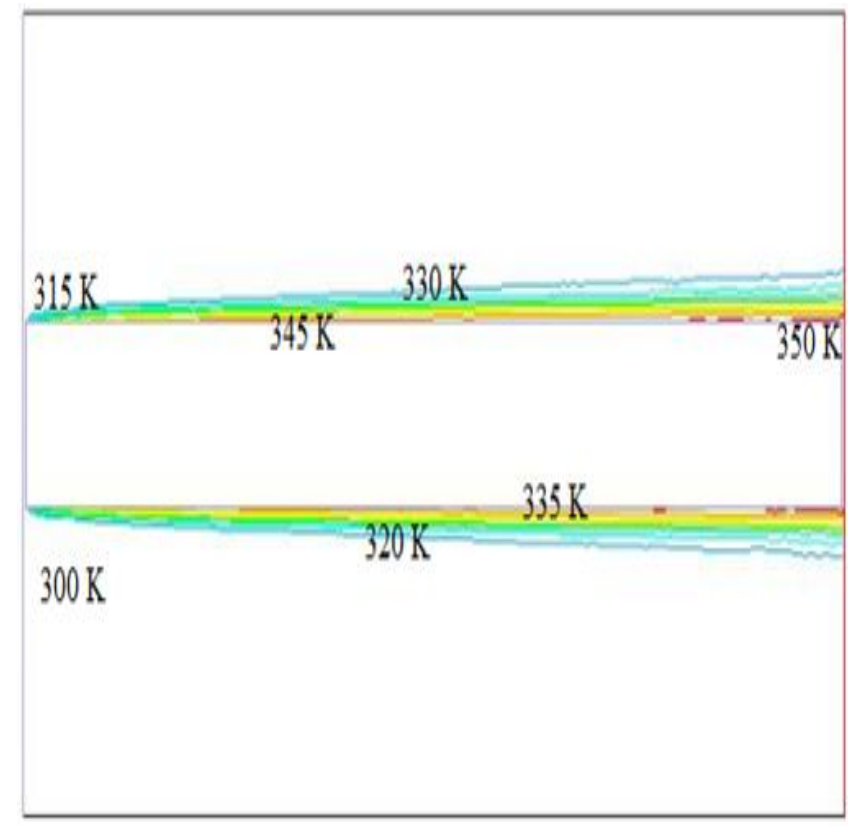

Figure 4. Temperature contour of water- $\mathrm{Al}_{2} \mathrm{O}_{3}$ nanofluid Here, simulation codes are implemented on water based $\mathrm{Al}_{2} \mathrm{O}_{3}$ nanofluid. The site visualizes on fuel cell heat management. This evaluates thermal field/contour and fuel cell temperature. Figure 3 demonstrates the thermal field only. The follow-on fuel cell temperature is $350 \mathrm{~K}$. It remains quite below the critical breakdown value of $356 \mathrm{~K}$. The thermal field ranges between $350 \mathrm{~K}$ at fuel cell edge and ambient $300 \mathrm{~K}$ at remotest field location. 
Figure 4 demonstrates only the thermal contour. Here too, thermal field ranges between $350 \mathrm{~K}$ at fuel cell edge and ambient $300 \mathrm{~K}$ at remotest field location.

\section{Effect of Water-SiC Nanofluid on Fuel Cell Cooling}

Here, simulation codes are implemented on water based $\mathrm{SiC}$ nanofluid. The site visualizes on fuel cell heat management. This evaluates thermal field/contour and fuel cell temperature. Figure 5 demonstrates the thermal field only. The follow-on fuel cell temperature is $322 \mathrm{~K}$. It remains quite below the critical breakdown value of $356 \mathrm{~K}$. The thermal field ranges between $322 \mathrm{~K}$ at fuel cell edge and ambient 300 $\mathrm{K}$ at remotest field location.

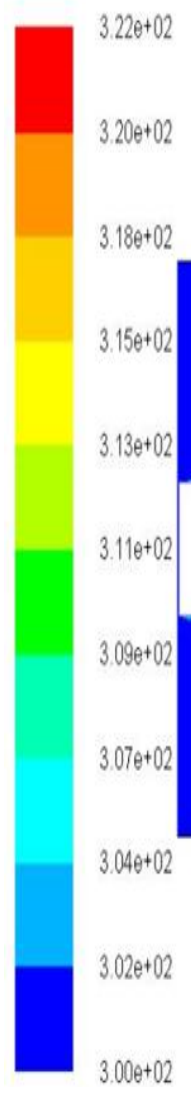

Figure 5. Temperature field with water-SiC nanofluid Figure 6 demonstrates only the thermal contour. Here too, thermal field ranges between $322 \mathrm{~K}$ at fuel cell edge and ambient $300 \mathrm{~K}$ at remotest field location.

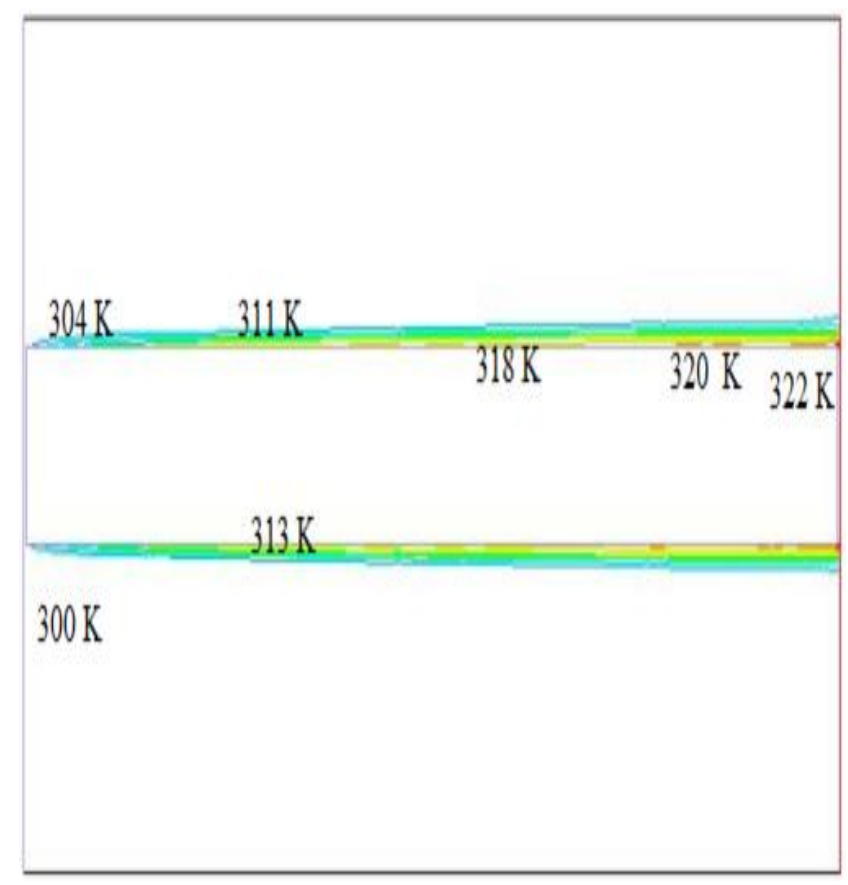

Figure 6. Temperature contour for water-SiC nanofluid

Effect of Water-CuO Nanofluid on Fuel Cell Cooling

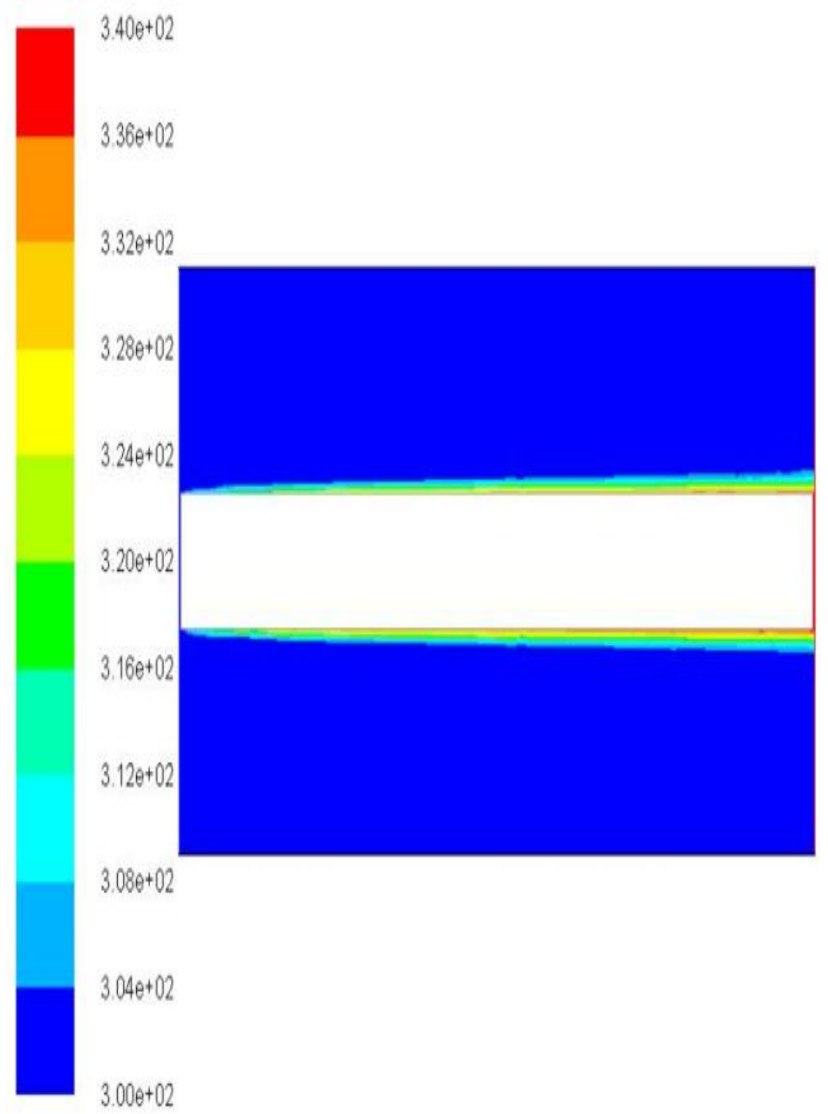

Figure 7. Temperature field with water-CuO nanofluid 


\section{Numerical Simulation and Modeling on Thermal Cooling of Fuel Cell Using Water Based $\mathrm{Al}_{2} \mathrm{O}_{3}, \mathrm{SiC}$ and $\mathrm{CuO}$ Nanofluids}

Here, simulation codes are implemented on water based $\mathrm{CuO}$ nanofluid. The site visualizes on fuel cell heat management. This evaluates thermal field/contour and fuel cell temperature. Figure 7 demonstrates the thermal field only. The follow-on fuel cell temperature is $340 \mathrm{~K}$. It remains quite below the critical breakdown value of $356 \mathrm{~K}$. The thermal field ranges between $340 \mathrm{~K}$ at fuel cell edge and ambient $300 \mathrm{~K}$ at remotest field location.

Figure 8 demonstrates only the thermal contour. Here too, thermal field ranges between $340 \mathrm{~K}$ at fuel cell edge and ambient $300 \mathrm{~K}$ at remotest field location.

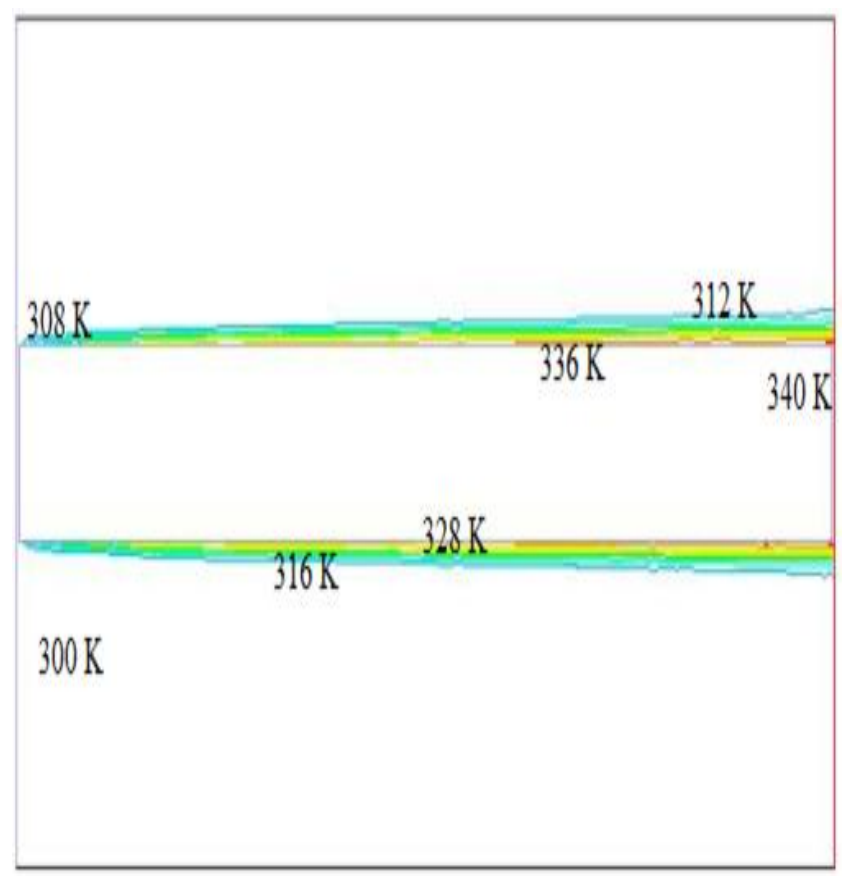

Figure 8. Temperature contour for water-CuO nanofluid

Table 2 retells the follow-on fuel cells temperatures of water based $\mathrm{Al}_{2} \mathrm{O}_{3}$, SiC and $\mathrm{CuO}$ nanofluids. Despite the resemblances in thermal fields/contours, the dissimilarities are in consequence of the deviances in thermophysical properties of nanomaterials enumerated in table 1.

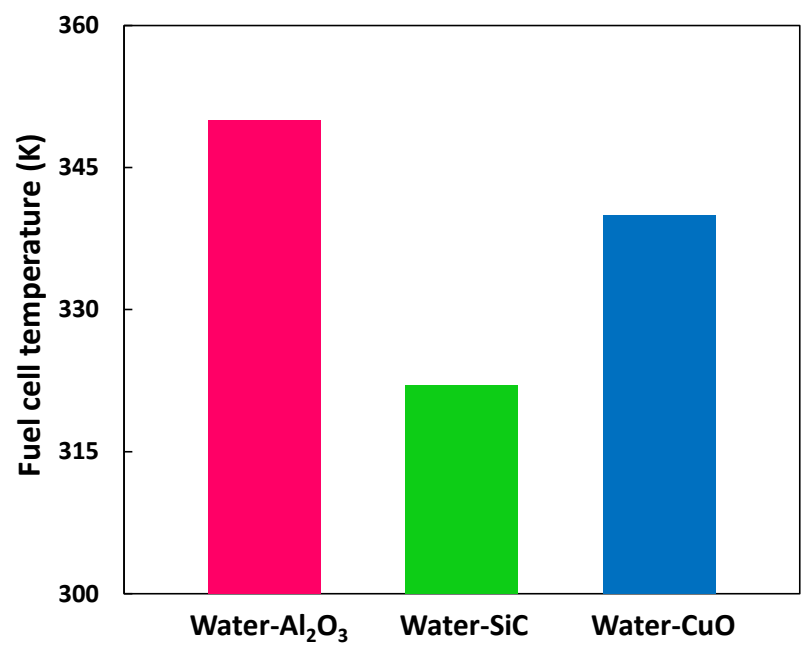

Figure 9. Fuel cell temperature vs. nanofluid

Figure 9 also presents the histogram of fuel cell temperature alongside nanofluid. Further, the water based SiC nanofluid extracts optimum fuel cell heat management.
Because, the water based SiC nanofluid corresponds to the minimum follow-on fuel cell temperature of $322 \mathrm{~K}$ as well.

Table 2. Summary of Fuel cell temperatures with nanofluids.

\begin{tabular}{|c|c|}
\hline Nanofluid & Fuel Cell Temperature (K) \\
\hline Water- $\mathrm{Al}_{2} \mathrm{O}_{3}$ & 350 \\
\hline Water-SiC & 322 \\
\hline Water-CuO & 340 \\
\hline
\end{tabular}

\section{CONCLUSION}

Simulation codes remain engendered and instigated on water based $\mathrm{Al}_{2} \mathrm{O}_{3}$, SiC and $\mathrm{CuO}$ nanofluids. The situation visualizes on fuel cell heat management. It evaluates thermal field/contour besides fuel cell temperature. Ultimately, for all the quoted nanofluids, the fuel cells temperatures remain quite below the critical breakdown value of 356 K. Furthermore, for all the quoted nanofluids, the thermal fields/contours range between fuel cells edges and ambient values. Despite the resemblances in thermal fields/contours, the dissimilarities are in consequence of the deviances in thermophysical properties of enumerated nanomaterials. Besides, fuel cell temperatures of $350 \mathrm{~K}, 322 \mathrm{~K}$ and $340 \mathrm{~K}$ are observed with water based $\mathrm{Al}_{2} \mathrm{O}_{3}, \mathrm{SiC}$ and $\mathrm{CuO}$ nanofluids, respectively. In addition, the water based $\mathrm{SiC}$ nanofluid extracts optimum fuel cell heat management. Because, the water based $\mathrm{SiC}$ nanofluid stands for the minutest ensuing fuel cell temperature of $322 \mathrm{~K}$ on top.

\section{ACKNOWLEDGMENT}

The essential support from VSSUT Burla for realizing this investigation is greatly acknowledged. Indeed, the author is grateful to the reviewers and journal editorial board for their meticulous and insightful reviews to this article.

\section{REFERENCES}

1. N. K. Kund, P. Dutta, 2010, Numerical simulation of solidification of liquid aluminium alloy flowing on cooling slope, Trans. Nonferrous Met. Soc. China, Vol. 20, pp. s898-s905.

2. N. K. Kund, P. Dutta, 2012, Scaling analysis of solidification of liquid aluminium alloy flowing on cooling slope, Trans. Indian Institute of Metals, Vol. 65, pp. 587-594.

3. N. K. Kund, 2014, Influence of melt pouring temperature and plate inclination on solidification and microstructure of A356 aluminum alloy produced using oblique plate, Trans. Nonferrous Met. Soc. China, Vol. 24, pp. 3465-3476.

4. N. K. Kund, 2015, Influence of plate length and plate cooling rate on solidification and microstructure of A356 alloy produced by oblique plate, Trans. Nonferrous Met. Soc. China, Vol. 25, pp. 61-71.

5. N. K. Kund, P. Dutta, 2015. Numerical study of solidification of A356 aluminum alloy flowing on an oblique plate with experimental validation, J Taiwan Inst. Chem. Ers., Vol. 51, pp. 159-170.

6. N. K. Kund, P. Dutta, 2016, Numerical study of influence of oblique plate length and cooling rate on solidification and macrosegregation of A356 aluminum alloy melt with experimental comparison, J. Alloys Compd., Vol. 678, pp. 343-354.

7. N. K. Kund, 2018, Effect of tilted plate vibration on solidification and microstructural and mechanical properties of semisolid cast and heat-treated A356 Al alloy, Int. J. Adv. Manufacturing Technol., Vol. 97, pp. 1617-1626.

8. N. K. Kund, 2019, EMS route designed for SSM processing, International Journal of Engineering and Advanced Technology, Vol. 8, pp. 382-384. 
9. N. K. Kund, 2019, Cooling slope practice for SSF technology, International Journal of Engineering and Advanced Technology, Vol. 8, pp. 410-413.

10. N. K. Kund, 2019, Comparative ways and means for production of nondendritic microstructures, International Journal of Innovative Technology and Exploring Engineering, Vol. 8, pp. 534-537.

11. N. K. Kund, 2019, Simulation of electronics cooling deploying water-zinc oxide nanofluid, International Journal of Recent Technology and Engineering, Vol. 7, pp. 1076-1078.

12. N. K. Kund, 2019, Numerical studies on fuel cell cooling introducing water-copper nanofluid, International Journal of Recent Technology and Engineering, Vol. 7, pp. 1079-1081.

13. N. K. Kund, 2019, Computational modeling of fuel cell expending water-zinc oxide nanofluid, International Journal of Innovative Technology and Exploring Engineering, Vol. 8, pp. 424-426.

14. N. K. Kund, 2019, Investigations on modeling and simulation of electronics cooling exhausting water-aluminum nanofluid, International Journal of Innovative Technology and Exploring Engineering, Vol. 8, pp. 660-663.

15. N. K. Kund, 2019, Numerical study on effect of nozzle size for jet impingement cooling with water- $\mathrm{Al}_{2} \mathrm{O}_{3}$ nanofluid, International Journal of Engineering and Advanced Technology, Vol. 8, pp. 736-739.

16. N. K. Kund, 2019, Experimental investigations on impacts of nozzle diameter on heat transfer behaviors with water jet impingement, International Journal of Engineering and Advanced Technology, Vol. 8, pp. 745-748.

17. N. K. Kund, 2019, Comparative CFD studies on jet impingement cooling using water and water- $\mathrm{Al}_{2} \mathrm{O}_{3}$ nanofluid as coolants, International Journal of Innovative Technology and Exploring Engineering, Vol. 8, pp. 545-548.

18. N. K. Kund, 2019, Experimental studies on effects of jet Reynolds number on thermal performances with striking water jets, International Journal of Innovative Technology and Exploring Engineering, Vol. 8, pp. 2195-2198.

19. N. K. Kund, D. Singh, 2019, CFD studies on heat transfer and solidification progress of A356 al alloy matrix and Al2 O3 nanoparticles melt for engineering usages, International Journal of Innovative Technology and Exploring Engineering, Vol. 8, pp. 2043-2046.

20. N. K. Kund, S. Patra, 2019, Simulation of thermal and solidification evolution of molten aluminum alloy and $\mathrm{SiC}$ nanoparticles for engineering practices, International Journal of Innovative Technology and Exploring Engineering, Vol. 8, pp. 2047-2050.

21. N. K. Kund, 2019, Numerical Modeling on Heat Dissipation from Electronics through Water-Titanium Carbide Nanofluid, International Journal of Innovative Technology and Exploring Engineering, Vol. 8.

22. N. K. Kund, 2019, CFD Modeling on Influence of Impinging Spout Strength for Device Cooling with Water-Al2O3 Nanofluid, International Journal of Innovative Technology and Exploring Engineering, Vol. 8.

23. N. K. Kund, 2019, Computational Modeling on Fuel Cell Cooling with Water Based Copper Oxide Nanofluid, International Journal of Innovative Technology and Exploring Engineering, Vol. 8.

24. N. K. Kund, 2019, Modeling and Simulation on IC Cooling Using Water Centered $\mathrm{SiO} 2, \mathrm{TiC}$ and $\mathrm{MgO}$ Nanofluids, International Journal of Innovative Technology and Exploring Engineering, Vol. 8.

25. N. K. Kund, 2019, CFD Simulation on IC Thermal Cooling through Water Involved TiO2, AlN and CuO Nanofluids, International Journal of Innovative Technology and Exploring Engineering, Vol. 8.

\section{Authors ProfiLe}

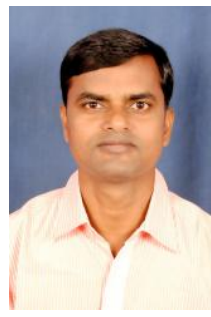

Dr. N. K. Kund has obtained both M.Tech. \& Ph.D. in Mechanical Engineering from Indian Institute of Science Bangalore. He has also obtained B.Tech.(Hons) in Mechanical Engineering from IGIT Sarang, Utkal University Bhubaneswar. He has published several research papers in international journals and also guided many research scholars, besides, wide teaching and research experience. He is presently working as Associate Professor in the Department of Production Engineering, VSSUT Burla (A Government Technical University). 